\title{
The Effect of Inorganic Nano Powder Additives in TEGDME for Lithium Air Batteries
}

\author{
M. Kartal*, M. Uysal, T. Cetinkaya, A. Alp, H. Akbulut \\ Sakarya University Engineering Faculty, Department of Metallurgical \& Materials Engineering, \\ Esentepe Campus, 54187, Sakarya, Turkey
}

\begin{abstract}
$\mathrm{SiO}_{2}$ and $\mathrm{Al}_{2} \mathrm{O}_{3}$ nano fillers were added to an electrolyte composed of a solution $1 \mathrm{M} \mathrm{LiPF}$ in tetra ethylene glycol dimethyl ether (TEGDME) and the effects of these nano powders on capacity and cycling performances were investigated. Galvanostatic charge/discharge (GC) measurements were performed in the assembled Li-air cells by using the nanocomposite electrolytes. The discharge capacities of these cells were cyclically tested by a battery tester at a constant current in the voltage range between $2.15 \mathrm{~V}$ and $4.25 \mathrm{~V}$. Discharge products of nanocomposite electrolytes were characterized by SEM and XRD spectroscopies. The electrochemical results demonstrated that $\mathrm{Al}_{2} \mathrm{O}_{3}$ reinforced electrolyte showed higher discharge capacity and cyclability than those of $\mathrm{SiO}_{2}$ reinforced electrolyte.
\end{abstract}

DOI: $10.12693 /$ APhysPolA.127.1016

PACS: 88.80.F-, 88.80.ff, 82.45.Gj, 82.45.Wx, 81.07.-b.

A breakthrough in entrodyction density is required to satisfy the energy storage needs of society in the long-term. Due to its high theoretical specific energy, lithium-air battery system is an extremely attractive technology for electrical energy storage, that could make long-range electric vehicles widely affordable. Lithium-air batteries have ultrahigh theoretical specific energies of $11 \mathrm{kWh} \mathrm{kg}^{-1}$, if based on the lithium electrode alone, or about $5.2 \mathrm{kWh} \mathrm{kg}^{-1}$, when the oxygen weight is included, almost 10 times that of the state-of-the-art Li-ion battery technology $[1,2]$. However, in practical sense, there are significant barriers still have to be overcome before the practical application of rechargeable Li-air batteries is possible. Dendrite formation of Li metal anode and its high reactivity with air still remain the challenges to overcome [3]. It is well known that the reduced oxygen species are generated on the cathode-electrolyte interface during the discharge process of the Li-air battery $[4,5]$. These species are chemically reactive and may cause decomposition of all battery components; electrolyte (solvent, salt and additives), cathode supporting materials (substrate; typically carbon, binder and current collector), and even separator [6]. Therefore, insulative decomposed products are formed on a cathode and cause a rapid capacity fading.

The electrolyte has a key role in non-aqueous lithiumair batteries because of its fundamental importance in producing the appropriate reversible electrochemical reduction. Tetra ethylene glycol dimethyl ether (TEGDME) is known by its higher specific capacity, as compared to carbonates and the other ethers; moreover, it is more stable to form $\mathrm{Li}_{2} \mathrm{O}_{2}$ in the first cycles. However, it has a low cycling performance [7].

Several studies has been reported to add ceramic nano fillers to aprotic solvents, especially polymer electrolytes

*corresponding author; e-mail: kartal@sakarya.edu.tr for lithium batteries. By this approach, it is found that there was an increase in conductivity and mechanical strength [8].

In this study, $\mathrm{SiO}_{2}$ and $\mathrm{Al}_{2} \mathrm{O}_{3}$ nano fillers are added to an electrolyte composed of a solution of $\mathrm{LiPF}_{6}$ in TEGDME. A lithium foil was used as an anode material and a gas diffusion layer (GDL) was used as a cathode material. $1 \mathrm{M}$ of $\mathrm{LiPF}_{6}$ and TEGDME electrolyte has been produced and amount of 0.1 wt. $\% \mathrm{Al}_{2} \mathrm{O}_{3}$ and $\mathrm{SiO}_{2}$ were added to this solution in order to compare the effects on efficiency of the Li-air cells. The effects on capacity and cycling performances and the properties of the as-produced electrolytes were investigated and characterized by using XRD and SEM spectroscopies. The electrochemical properties of the electrolytes were also tested in order to evaluate the battery performance.

\section{Experimental details}

\subsection{Cell assembly}

The gas diffusion layers (GDLs) (SIGRACET 24BC, SGL Carbon Inc.) with an area of $2.54 \mathrm{~cm}^{2}$ were dried overnight at $55^{\circ} \mathrm{C}$. Anhydrous TEGDME was purchased from Alfa Aesar and treated with molecular sieves to remove the impurities prior to use as the electrolyte. A lithium foil disk was used as an anode material and a gas diffusion layer (GDL) was used as a cathode material, while glass fiber $(18 \times 0.65 \mathrm{~mm}, \mathrm{ECC} 1-01-0012-\mathrm{A} / \mathrm{L})$ saturated in the electrolyte was used as a separator. A solution of $1 \mathrm{M} \mathrm{LiPF}_{6}$ (Aldrich) in tetra (ethylene glycol) dimethyl ether (tetraglyme, Aldrich) was used as the electrolyte. Lithium hexafluorophosphate $\left(\mathrm{LiPF}_{6}\right)$ $\left(>98.0 \%\right.$ ) was dried at $50{ }^{\circ} \mathrm{C}$ for 3 hours under argon atmosphere. $\mathrm{Al}_{2} \mathrm{O}_{3}(>99.99 \%,<50 \mathrm{~nm})$ and $\mathrm{SiO}_{2}$ $(>99.99 \%,<80 \mathrm{~nm})$ were also dried at $100{ }^{\circ} \mathrm{C}$ for 72 hours to remove humidity. $1 \mathrm{M} \mathrm{LiPF}_{6}$ in TEGDME electrolyte was prepared and ratio of $0.1 \mathrm{wt} . \% \mathrm{Al}_{2} \mathrm{O}_{3}$ and $0.1 \mathrm{wt} . \% \mathrm{SiO}_{2}$ added to solvent and mixed vigorously by magnetic stirring and stored in amber glass sample vials 
in an MBraun dry box filled with purified argon. The moisture and oxygen content were less than $1 \mathrm{ppm}$.

The Li-air cell was then assembled in an Ar-filled dry glove box (MBraun LABstar) using an ECC-Air electrochemical cell (EL-Cell, GmbH) configuration with openings allowing oxygen to inlet and outlet through the cathodic side.

\subsection{Characterizations of electrolytes}

Conductivity tests were carried out by using Eutech Instruments PCD 650 Multiparameter at room temperature under argon atmosphere and viscosity tests were applied by AAND SV-10 Viscometer at room temperature under air atmosphere. The morphology of the discharge products on cathode was observed by scanning electron microscopy (SEM) (JSM-6060 LV system). Surface characterization of the discharged cathode was also investigated by X-ray diffraction (XRD) (Rigaku D/MAX 2000). The cells were cyclically tested on a MTI Model BST8-MA electrochemical analyzer using $0.10 \mathrm{~mA} / \mathrm{cm}^{2}$ current density over a voltage range of $2.15-4.25 \mathrm{~V}$ and the oxygen gas flow rate was $15 \mathrm{ml} / \mathrm{sec}$. All electrochemical measurements were carried out at room temperature $\left(25{ }^{\circ} \mathrm{C}\right)$.

\section{Result and discussion}

Figure $1 \mathrm{a}$ and $1 \mathrm{~b}$ show the viscosity and the conductivity of the electrolytes. Predictably, addition of $\mathrm{Al}_{2} \mathrm{O}_{3}$ and $\mathrm{SiO}_{2}$ nano powder resulted in a slight increase in the viscosity, while the conductivity of the nanocomposite electrolytes slightly decreased, as compared to the base electrolyte with the same $\mathrm{LiPF}_{6}$ content. Finer particle sized $\mathrm{Al}_{2} \mathrm{O}_{3}$ nano-powder-reinforced electrolyte has increased the viscosity but showed a slightly higher conductivity than that of $\mathrm{SiO}_{2}[9]$.

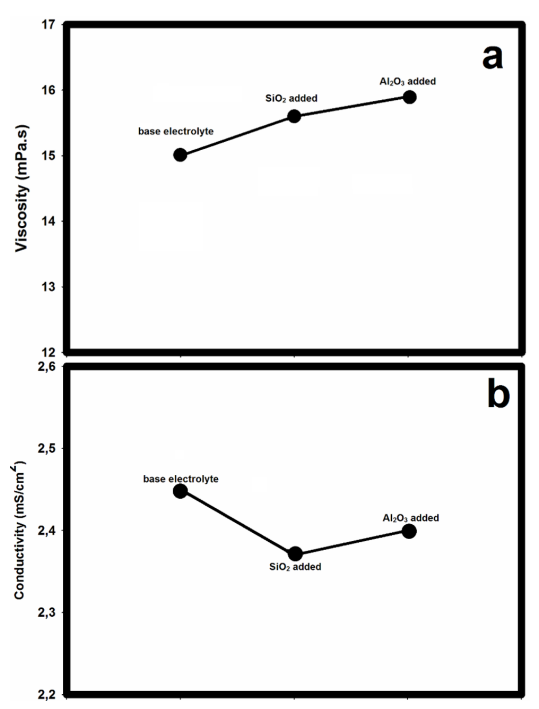

Fig. 1. The influences of the nano fillers on a) viscosity, b) conductivity.

Figure 2 shows the cathode surfaces of the nanocomposite electrolytes after 10 cycles. It is found that both nano fillers have accumulated on the surface with the discharge products and thus have occluded the pores. It is

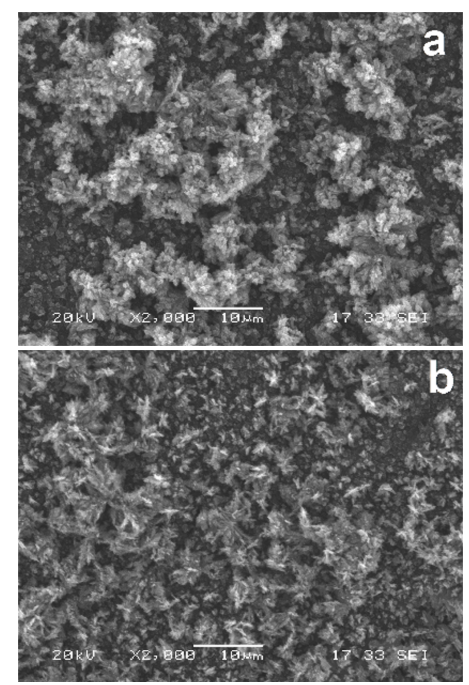

Fig. 2. SEM images of the cathodes working with electrolytes including a) $0.1 \mathrm{wt} \% \mathrm{SiO}_{2}$, b) $0.1 \mathrm{wt} \% \mathrm{Al}_{2} \mathrm{O}_{3}$.

also obvious that $\mathrm{SiO}_{2}$ powders are more prone to accumulation on the cathode surface with aggregation. This is because of particle size of the powders. $\mathrm{Al}_{2} \mathrm{O}_{3}$ nano fillers are randomly dispersed in the microstructure and do not exhibit the coarsened microstructure of $\mathrm{SiO}_{2}$ powders.

X-ray diffraction patterns of the two different electrolytes are shown in Fig. 3. The typical reflection peak of carbon is observed. $\mathrm{SiO}_{2}$ and $\mathrm{Al}_{2} \mathrm{O}_{3}$ peaks are also appeared with the discharge products; $\mathrm{Li}_{2} \mathrm{CO}_{3}$ is the predominant and $\mathrm{Li}_{2} \mathrm{O}_{2}, \mathrm{LiO}_{2}$ are the by-products.

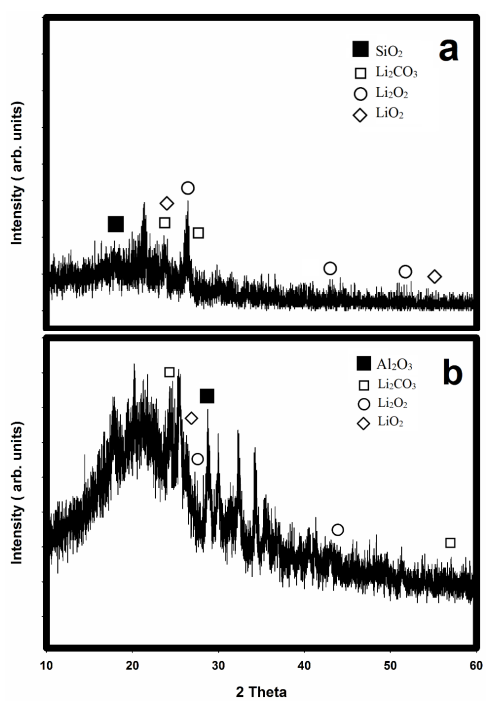

Fig. 3. XRD peaks of the electrolytes including a) $0.1 \mathrm{wt} \% \mathrm{SiO}_{2}$, b) $0.1 \mathrm{wt} \% \mathrm{Al}_{2} \mathrm{O}_{3}$.

Figure 4 displays the performance at first three cycles of the nanocomposite electrolytes, produced with addition of two different nano fillers, at a current density of $0.10 \mathrm{~mA} / \mathrm{cm}^{2}$ and potential between 2.15 and $4.25 \mathrm{~V}$. As shown in Fig. 4b, the electrolyte containing 0.1 wt.\% $\mathrm{Al}_{2} \mathrm{O}_{3}$ exhibited approximately two times higher capac- 


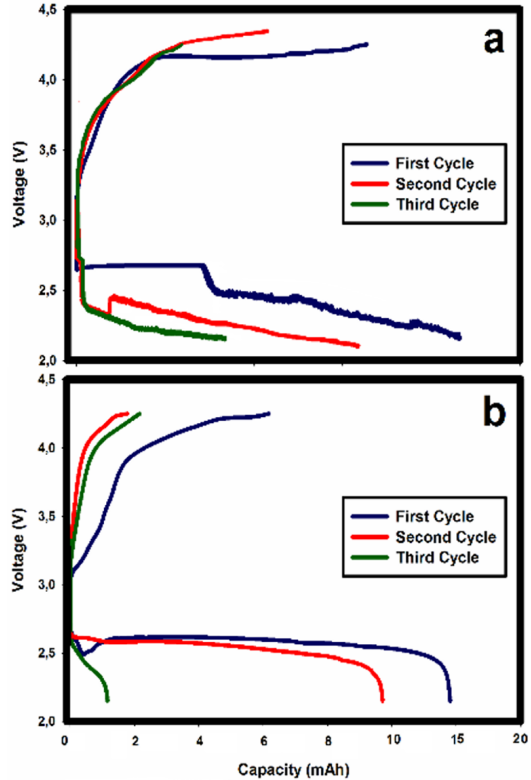

Fig. 4. The first three cycles of the electrolytes including; a) $0.1 \mathrm{wt} \% \mathrm{SiO}_{2}$, b) $0.1 \mathrm{wt} \% \mathrm{Al}_{2} \mathrm{O}_{3}$.

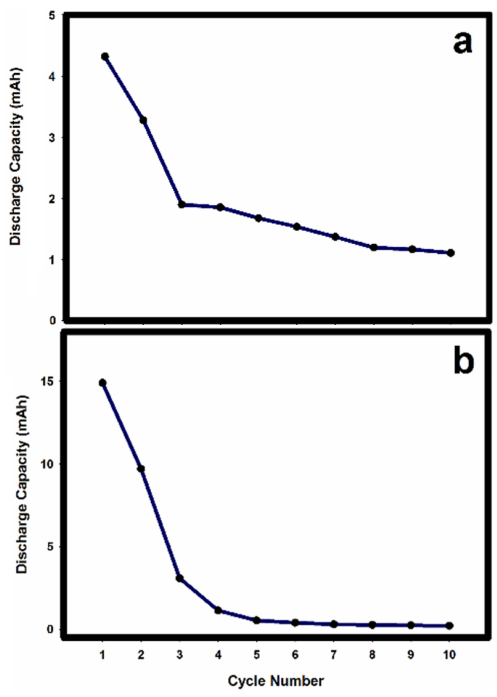

Fig. 5. The effects of the nano fillers on cycle performance a) 0.1 wt $\% \mathrm{SiO}_{2}$, b) 0.1 wt $\% \mathrm{Al}_{2} \mathrm{O}_{3}$.

ities than 0.1 wt.\% $\mathrm{SiO}_{2}$ at the first two cycles, but the capacities have rapidly decreased at the third cycle. This can be related to occlusion of cathode pores with correspondingly finer particle-sized $\mathrm{Al}_{2} \mathrm{O}_{3}$ and also with the decomposition of the solvent [10]. As demonstrated in Fig. 4a, $\mathrm{SiO}_{2}$-reinforced electrolyte demonstrated relatively better coulombic efficiency and stability than $\mathrm{Al}_{2} \mathrm{O}_{3}$-reinforced electrolyte, but quite lower capacities were obtained at the first two cycles.

Figure 5 shows the ten-cycle-performances of the nanocomposite electrolytes containing two different nano fillers at a current density of $0.10 \mathrm{~mA} / \mathrm{cm}^{2}$ and potential between 2.15 and $4.25 \mathrm{~V} . \mathrm{SiO}_{2}$ added electrolyte showed higher stability but lower initial capacities than
$\mathrm{Al}_{2} \mathrm{O}_{3}$ added electrolyte. Since the discharge products and $\mathrm{SiO}_{2}$ particles, substantially deposited on the cathode surface, formed amorphous and porous layer, a limited cathode surface area is observed. This resulted in a relatively lower capacity performance but higher cyclic performance than in $\mathrm{Al}_{2} \mathrm{O}_{3}$-added electrolyte [11]. Depending on the pore sizes of the cathode, finer $\mathrm{Al}_{2} \mathrm{O}_{3}$ particles were well dispersed on the surface, but have penetrated into the pores and hindered the oxygen transfer into the lithium air cell, which resulted in $0.472 \mathrm{mAh}$ at $10^{\text {th }}$ cycle, while the $\mathrm{SiO}_{2}$-added electrolyte showed $1.266 \mathrm{mAh}$ at the same cycle.

\section{Conclusions}

Nanocomposite electrolytes were produced from $1 \mathrm{M}$ $\mathrm{LiPF}_{6}$ in TEGDME with $\mathrm{SiO}_{2}, \mathrm{Al}_{2} \mathrm{O}_{3}$ additives, and prepared by using magnetic stirring. The main conclusions of the investigation are as follows: The surface morphology of the cathode was affected by inorganic additives, and relatively higher discharge capacities were obtained at the first two cycles in $\mathrm{Al}_{2} \mathrm{O}_{3}$-added electrolyte. However $\mathrm{SiO}_{2}$ demonstrated more stable charge/discharge characteristic than that of $\mathrm{Al}_{2} \mathrm{O}_{3}$-added nanocomposite electrolyte. Respectively a high reversible capacity, and fairly good cyclability was achieved for $1 \mathrm{M} \mathrm{LiPF}_{6}$ in TEGDME with 0.1 wt. $\% \mathrm{SiO}_{2}$ addition.

\section{References}

[1] L.J. Hardwick, P.G. Bruce, Curr. Opin. Solid State M. 16, 178 (2012).

[2] W. Xu, J. Hu, M.H. Engelhard, S.A. Towne, J.S. Hardy, J. Xiao, J. Feng, M.Y. Hu, J. Zhang, F. Ding, M.E. Gross, J.G. Zhang, J. Power Sources 215, 240 (2012).

[3] F. Mizuno, K. Takechi, S. Higashi, T. Shiga, T. Shiotsuki, N. Takazawa, Y. Sakurabayashi, S. Okazaki, I. Nitta, T. Kodama, H. Nakamoto, H. Nishikoori, S. Nakanishi, Y. Kotani, H. Iba, J. Power Sources 228, 47 (2013).

[4] C.O. Laoire, S. Mukerjee, K.M. Abraham, E.J. Plichta, M.A. Hendrickson, J. Phys. Chem. C 113, 20127 (2009).

[5] B.D. McCloskey, R. Scheffler, A. Speidel, G. Girishkumar, A.C. Luntz, J. Phys. Chem. C 116, 23897 (2012).

[6] E. Nasybulin, W. Xu, M.H. Engelhard, Z. Nie, X.S. Li, J.G. Zhang, J. Power Sources 243, 899 (2013).

[7] C.Ó. Laoire, S. Mukerjee, E.J. Plichta, M.A. Hendrickson, K.M. Abraham, J. Electrochem. Soc. 158, A302 (2011).

[8] H. Tokuda, M. Watanabe, Electrochim. Acta 48, 2085 (2003)

[9] D. Sharma, A. Mukherjee, International Journal of Emerging Technology and Advanced Engineering 4, 60 (2014).

[10] B.D. McCloskey, A. Speidel, R. Scheffler, D.C. Miller, V. Viswanathan, J.S. Hummelshøj, J.K. Nørskov, A.C. Luntz, J. Phys. Chem. Lett. 3, 997 (2012).

[11] M. Balaish, A. Kraytsberg, Y. Ein-Eli, Phys. Chem. Chem. Phys. 16, 2801 (2013). 